Rheum Dis Clin North Am. 2014 May ; 40(2): 155-175. doi:10.1016/j.rdc.2014.01.001.

\title{
Epidemiology of Gout
}

\section{Edward Roddy, DM FRCP ${ }^{1}$ and Hyon Choi, MD, DrPH ${ }^{2}$}

${ }^{1}$ Senior Lecturer in Rheumatology, Research Institute for Primary Care and Health Sciences, Keele University, Keele, Staffordshire, UK. Tel: 00441782734715 Fax: 00441782733911

e.roddy@keele.ac.uk

2Professor of Medicine, Boston University School of Medicine, Section of Rheumatology and the Clinical Epidemiology Unit, 650 Albany Street, Suite 200, Boston, MA 02118, Tel: 0001617638 5490 Fax: 00016176385239 hchoius@bu.edu

\section{Synopsis}

Gout is the most prevalent inflammatory arthritis in men. The findings of several epidemiological studies from a diverse range of countries suggest that the prevalence of gout has risen over the last few decades. Whilst incidence data are scarce, data from the US suggests that the incidence of gout is also rising. Evidence from prospective epidemiological studies has confirmed dietary factors (animal purines, alcohol and fructose), obesity, the metabolic syndrome, hypertension, diuretic use, and chronic kidney disease as clinically relevant risk factors for hyperuricemia and gout. Low-fat dairy products, coffee, and vitamin $\mathrm{C}$ appear to have a protective effect. Further prospective studies are required to examine other proposed risk factors for hyperuricaemia and gout such as the use of $\beta$-blockers and angiotension-II receptor antagonists (other than losartan), obstructive sleep apnoea, and osteoarthritis, and putative protective factors such as calciumchannel blockers and losartan.

\section{Keywords}

Gout; Hyperuricaemia; Prevalence; Incidence; Aetiology; Epidemiology

\section{Introduction}

Gout is a crystal deposition disease which arises when supersaturation of body tissues with urate occurs, leading to the formation of monosodium urate crystals (MSU) in and around joints. It is the most prevalent inflammatory arthritis in men and is associated with impaired quality of life [1]. Clinical manifestations include excruciatingly painful acute attacks of gouty arthritis, the formation of tophaceous MSU crystal deposits in joints and other body tissues, chronic joint damage, renal stone formation, and potential renal insufficiency.

\footnotetext{
(C) 2014 Elsevier Inc. All rights reserved.

Correspondence to: Edward Roddy.

Publisher's Disclaimer: This is a PDF file of an unedited manuscript that has been accepted for publication. As a service to our customers we are providing this early version of the manuscript. The manuscript will undergo copyediting, typesetting, and review of the resulting proof before it is published in its final citable form. Please note that during the production process errors may be discovered which could affect the content, and all legal disclaimers that apply to the journal pertain.
} 
This chapter will review trends in the prevalence and incidence of gout and the epidemiological evidence underpinning our understanding of aetiological factors for its development including hyperuricaemia, dietary factors, comorbidities (metabolic syndrome, renal disease and osteoarthritis (OA)), and medications. The burden of co-morbidity associated with and caused by gout will be considered in Chapter 6 . Where possible, priority has been given to population-based prospective epidemiological studies (Table 1).

\section{Prevalence of gout}

Data from a number of countries suggest that gout is becoming more prevalent (Table 2). In the USA, the National Health Interview Surveys asked participants about members of their household having gout within the preceding year. The one-year period prevalence of selfreported gout increased from 4.8/1000 in 1969 to 7.8/1000 in 1976, increasing further to $8.3 / 1000$ in 1980 [2]. Since then, the prevalence has remained fairly stable at 8.4-9.9/1000 [3], with the most recently published estimate being 9.4/1000 in 1996 [4]. Similarly, the National Health and Nutrition Examination Survey (NHANES) found that the self-reported lifetime prevalence of physician-diagnosed gout increased from 26.4/1000 in NHANES III (1988-1994) to 37.6/1000 in NHANES 2007-2010 [5]. Furthermore, serum uric acid level (the key causal precursor of gout and primary end-point by the FDA for gout drug approval) has increased over the interval between the two NHANES studies [6]. Gout-related claims in an administrative claims database increased from 2.9/1000 in 1990 to 5.2/1000 in 1999 [7].

In the UK, the estimated lifetime prevalence of gout was 2.6/1000 in 1975, 3.4/1000 in 1987 and 9.5/1000 in 1993 [8-10]. In the General Practice Research Database (GPRD), the oneyear consultation prevalence of gout was 13.9/1000 in 1999 [11]. A similar consultation prevalence of 14.0/1000 was seen in the IMS Disease Analyzer between 2000 and 2005 [12]. Subsequently, the Royal College of General Practitioners Weekly Returns Service (RCGP-WRS) found that the annual prevalence appeared to increase slightly from 4.3/1000 in 2001 to $4.7 / 1000$ in 2007 [13].

Comparison of data from successive surveys undertaken in New Zealand using similar methods shows a marked increase in the prevalence of gout in both European and Maori subjects [14-16]. Lifetime prevalence estimates in 1958, 1966 and 1992 were 3/1000, 9/1000 and 29/1000 in European subjects respectively. Corresponding estimates in Maori subjects were 27/1000, 60/1000 and 64/1000 respectively. More recently, a nationwide study that used different methods of sampling and case ascertainment showed similar prevalence estimates (i.e. 32/1000 for European subjects and 61/1000 for Maori subjects) [17].

Data from China also suggest that gout is becoming more prevalent. Successive random population surveys in the city of Qingdao, found the prevalence of gout to be 3.6/1,000 in 2002 increasing to 5.3/1,000 in $2004[18,19]$.

There is notable variation in the prevalence of gout obtained in these studies. This is likely explained by a combination of differing methods used for sampling and case ascertainment and definition, different time-periods for prevalence estimation (i.e. confined-period prevalence vs. lifetime prevalence), demographics, and differences in genetic, lifestyle, and 
co-morbid risk factor profiles in different geographical populations. However, comparison of estimates within the same countries and within the same datasets reduces the impact of this methodological and clinical heterogeneity, and provides sufficient evidence that gout has become increasingly more common over the past few decades.

\section{Incidence of gout}

There are fewer studies examining the incidence of gout. In the USA, the John Hopkins Precursors Study recruited 1216 male medical students (mean age 22.2 years) between 1948 and 1964, following them for a mean period of 29 years [20]. Sixty men developed gout, corresponding to an incidence of 1.73 per 1000 person-years. The Health Professionals Follow-Up Study (HPFS) [21] followed 47,150 male health professionals for 12 years, identifying 730 cases of incident gout (incidence, 1.50 per 1,000 person-years, using the ACR survey criteria [22]). In an analysis nested within the Framingham Heart Study, 1951 men and 2476 women who were aged between 29 and 62 years and free of gout at recruitment in 1947 were followed-up for a median of 28 years [23]. Incidence of gout per 1000 person-years was 4.0 in men and 1.4 in women. Serial investigations of computerized medical records from the Rochester Epidemiology Project showed that the incidence of gout without diuretic exposure (using the ACR survey criteria [22]) doubled from 20.2/100,000 in 1977/78 to 45.9/100,000 in 1995/96, whereas the proportion of gout associated with diuretic use decreased significantly during this period [24].

In contrast to the Rochester Epidemiology Project, data from three primary care consultation database studies in the UK do not suggest that the incidence of gout is changing. Gout incidence remained fairly stable in the GPRD in the 1990s, ranging from 11.9 per 10,000 person-years in 1991 to 18.0 per 10,000 person-years in 1994, before decreasing back to 13.1 per 10,000 person-years in 1999 [11]. A study using the Health Improvement Network (THIN) UK primary care database followed 1,775,505 individuals, aged 20 to 89 years and free of gout at baseline, for an average of 5.2 years between January 2000 and December 2007 [25]. 24,768 cases of incident gout were identified, equating to a crude incidence rate of 2.68 per 1,000 person-years (incidence per 1,000 person-years was 4.42 in men and 1.32 in women), and incidence remained stable over the study period (2000-1: 2.67 per 1,000 person-years, 2006-7: 2.52 per 1,000 patient-years). Although the incidence of gout appears to be higher in the later THIN study than the earlier GPRD study, data from the RCGP-WRS found the mean annual incidence of gout to be 12.4 cases per 10,000 person-years between 1994 and 2007, without evidence of changing incidence over this period [13].

\section{Hyperuricaemia}

It has been well-established that hyperuricemia is the key causal precursor in the development of gout. Population studies have demonstrated and quantified a direct positive (linear to exponential) relation between serum urate levels and a future risk of gout, as summarized here. The Normative Aging Study followed 2,046 healthy male veterans aged 21 to 81 years over a period of 14.9 years, identifying 84 new cases of acute gouty arthritis [26]. The incidence of gout per 1,000 person-years in people with serum urate levels $<6.0 \mathrm{mg} / \mathrm{dl}, 6.0-6.9 \mathrm{mg} / \mathrm{dl}, 7.0-7.9 \mathrm{mg} / \mathrm{dl}, 8.0-8.9 \mathrm{mg} / \mathrm{dl}, 9.0-9.9 \mathrm{mg} / \mathrm{dl}$ and $\geq 10.0 \mathrm{mg} / \mathrm{dl}$ was 
0.8, 0.9, 4.1, 8.4, 43.2, and 70.2 respectively. In the Framingham Heart Study, there was a similar marked dose-dependent increase in both incidence and relative risk (RR) of developing gout with serum urate level (Figure 1) [23]. A study from Italy undertaken in the Health Search/Longitudinal Patient Primary Care database also found a dose-response relationship between serum urate levels at baseline and incident gout [27]. Compared to those with a serum urate level $<6 \mathrm{mg} / \mathrm{dl}$, the odds of incident gout were 1.75 (95\% CI 1.44, 2.12 ) with serum urate $6-7 \mathrm{mg} / \mathrm{dL}$, rising to 6.20 (95\% CI 5.32, 7.24) and $15.31(95 \% \mathrm{CI}$ $12.51,18.75)$ in those with serum urate $7-9 \mathrm{mg} / \mathrm{dl}$ and $\searrow 9 \mathrm{mg} / \mathrm{dl}$ respectively. In the Kinmen Study from Taiwan, 42 out of 223 men with hyperuricaemia but no history of gout at baseline in 1991 had developed gout when re-examined in 1996/7, corresponding to a fiveyear cumulative incidence of $18.8 \%$. [28]. The five-year cumulative incidence was $10.8 \%$ in those with a serum urate level of $7.0-7.9 \mathrm{mg} / \mathrm{dl}, 27.7 \%$ with a serum urate $8.0-8.9 \mathrm{mg} / \mathrm{dl}$, and $61.1 \%$ with a serum urate $\geqslant 9.0 \mathrm{mg} / \mathrm{dl}$. These studies, together with the fact that effective management of hyperuricemia prevents gout, provide convincing evidence that hyperuricaemia is a necessary casual component for the development of gout.

\section{Dietary factors}

Although an association between gout and dietary factors, particularly purine-rich foods and alcoholic beverages, has been recognised for centuries, it is only recently that robust epidemiological evidence of such have emerged (Table 3). The most comprehensive assessment of the association between gout and diet has been undertaken in the HPFS. In this large, prospective study, a semi-quantitative food frequency questionnaire was administered to 51,529 male health professionals at baseline and at four- and eight-year follow-up. Over a 12-year period, 730 incident cases of gout were identified. In addition to confirming the historical observations that excessive consumption of purine-rich foods and alcoholic drinks are independent risk factors for gout, evidence has been provided for more novel dietary associations: namely, that fructose and sugar-sweetened soft-drinks increase the risk of developing gout whereas dairy products, coffee, and vitamin $\mathrm{C}$ appear to be protective against the development of gout.

Purine-rich foods theoretically predispose to gout by providing exogenous substrate for purine metabolism, the end-product of which is uric acid in humans (Figure 2). Compared with men in the lowest quintile, men in the highest quintiles of total meat and seafood intake had an increased risk of incident gout of $41 \%$ and $51 \%$ respectively, adjusting for age, energy intake, body mass index (BMI), diuretic use, hypertension, renal failure, and dietary factors including alcohol (Table 3) [21]. Consumption of purine-rich vegetables was not a risk factor for incident gout. Men in the highest quintile of consumption of dairy products, particularly low-fat dairy, had almost half the risk of risk of incident gout compared to those in the lowest quintile. High-fat dairy consumption had no protective effect. The multivariate RRs per additional daily serving were $1.21(95 \% \mathrm{CI} 1.04,1.41)$ for total meat, 1.07 (95\% CI $1.01,1.12$ ) for seafood, 0.82 (95\% CI $0.75,0.90)$ for total dairy, and 0.79 (95\% CI 0.71, 0.87 ) for low-fat dairy. A recent randomized control trial (RCT) has found that intact milk intake has an acute uricosuric urate-lowering effect [29]. Proteins contained in milk, such as casein, lactoalbumin, and orotic acid may exert their uricosuric effects without the concomitant purine load contained in other animal protein sources such as meat and seafood 
[29,30]. Another RCT has suggested that skimmed milk powder derivatives have antiinflammatory effects against acute gout flares among patients with pre-existing gout [31].

Excessive consumption of purine-rich foods has been shown to trigger recurrent gout attacks in a novel internet-based case-crossover study in which each participant acts as their own control, thereby allowing the effect of transient exposures on an acute event to be studied whilst eliminating confounding due to individual characteristics that do not change during the study period [32]. In an analysis of 1,247 recurrent gout attacks occurring over a oneyear period in 633 participants, the multivariate OR for recurrent gout attacks for each increasing quintile of purine consumption were 1.17 (95\% CI 0.88, 1.55), 1.38 (95\% CI 1.02, 1.87), 2.21 (95\%CI 1.62, 3.01) and $4.76(3.37,6.74)$ respectively, compared with the lowest quintile over a two-day period and adjusted for use of alcohol, diuretics, allopurinol, colchicine and non-steroidal anti-inflammatory drugs.

Coffee is thought to reduce serum uric acid levels by a number of mechanisms (Figure 2). It is rich in anti-oxidants, such as the phenol chlorogenic acid, which are thought to increase insulin sensitivity [33,34] and in turn enhance renal urate excretion [35]. Caffeine is itself a methyl xanthine and may therefore be a competitive inhibitor of xanthine oxidase [36], the major enzyme in purine metabolic pathways. In a subsequent HPFS analysis, a dosedependent inverse relationship between the number of cups of coffee consumed per day and incident gout was seen ( 0 cups, RR 1.00 referent; <1 cup, RR 0.97, 95\%CI 0.78, 1.20; 1-3 cups, RR 0.92, 95\%CI 0.75, 1.11; 4-5 cups, RR 0.60, 95\%CI 0.41, 0.87; \6 cups, RR 0.41, $95 \%$ CI $0.19,0.88$ ) [37]. A similar more modest inverse association was seen between consumption of decaffeinated coffee and incident gout whereas no association was seen for either tea consumption or total caffeine intake. The association between coffee consumption and incident gout in women has been examined in the Nurses' Health Study [38]. 89,433 female nurses who were gout-free prior to baseline were followed-up for 26 years, during which 896 incident gout cases occurred. A similar inverse relationship was found between coffee consumption and risk of gout. Compared with women who drank no coffee, women who drank $\geq 948 \mathrm{mls}$ of coffee per day had less than half the risk of incident gout, after adjustment for age, total energy intake, BMI, menopause, use of hormonal replacement, diuretic use, hypertension and dietary factors (Table 3). As with men in the HPFS [37], there was a modest inverse relationship with decaffeinated coffee and no association with tea. In contrast to men in the HPFS, there was a negative association between total caffeine intake and incident gout. Women consuming $359-497 \mathrm{mg} / \mathrm{day}$ and $\geq 498 \mathrm{mg} / \mathrm{day}$ had $23 \%$ and $48 \%$ reduced risk respectively, compared with women consuming $\leq 131 \mathrm{mg} /$ day (Table 3 ).

Fructose acts as a substrate for uric acid production by enhancing degradation of purine nucleotides (Figure 2) [39]. Consumption of sugar-sweetened soft drinks has also been shown to increase the risk of incident gout in a dose-dependent manner in the HPFS [40]. Compared to men who consumed sugar-sweetened soft-drinks less frequently than once per month, the multivariate RR of incident gout was $1.29(95 \% \mathrm{CI} 1.00,1.68)$ in those consuming 5-6 servings per week, 1.45 (95\% CI 1.02, 2.08) with once daily consumption, and 1.85 (95\% CI 1.08. 3.16) in those consuming 2 or more servings per day. Consumption of diet soft-drinks was not a risk factor for incident gout. A positive dose-dependent relationship was also seen between free fructose intake and incident gout (quintile 1 referent; 
quintile 2, RR 1.29, 95\% CI 1.02, 1.64; quintile 3, RR 1.41, 95\% CI 1.09, 1.82; quintile 4, RR 1.84, 95\% CI 1.40, 2.41; quintile 5, RR 2.02, 95\% CI 1.49, 2.75). In the Nurses' Health Study, women drinking one serving of sugar-sweetened soft drinks per day and $\geq 2$ servings per day were at a $74 \%$ and $139 \%$ higher risk of incident gout respectively, compared to those consuming < 1 serving per month (Table 3) [41]. Compared to women in the lowest quintile of free fructose intake, the multivariate RRs of incident gout in the highest and second highest quintiles were $1.62(95 \%$ CI $1.20,2.19)$ and 1.34 (95\% CI 1.01, 1.76) respectively.

Vitamin C has recognised uricosuric properties (Figure 2) [42] and high vitamin C intake has been shown to be protective against the development of gout in the HPFS [43]. The multivariate RR of incident gout was $0.97(95 \% \mathrm{CI} 0.85,1.12)$ for total vitamin C consumption of $250-499 \mathrm{mg} /$ day, 0.83 (95\% CI $0.71,0.97$ ) for $500-999 \mathrm{mg} /$ day, 0.66 (95\% CI $0.52,0.86)$ for $1000-1499 \mathrm{mg} / \mathrm{day}$, and $0.55(95 \% \mathrm{CI} 0.38,0.80)$ for $\geq 1500 \mathrm{mg} / \mathrm{day}$, compared with those consuming less than $250 \mathrm{mg}$ per day.

Cherries and cherry extract have recognised urate-lowering properties and hence have attracted much interest as a potential treatment for gout. However, epidemiological evidence of the association between cherry consumption and gout is sparse. In the internet-based case-crossover study described above, intake of cherries (multivariate OR $0.65 ; 95 \% \mathrm{CI}$ $0.50,0.85$ ) and cherry extract (OR $0.55 ; 95 \%$ CI $0.30,0.98$ ) over the preceding two-day period both appeared to be protective against recurrent gout attacks [44].

\section{Alcohol consumption}

Several studies have examined the long-recognised observation that alcohol consumption is a risk factor for the development of gout (Table 3). Alcohol consumption is thought to predispose to gout by providing substrate for purine metabolism in the form of guanosine (particularly beer), enhancing nucleotide turnover, and impairing renal urate excretion via lactic acidosis (Figure 2) [45]. The Atherosclerosis Risk in Communities (ARIC) study was a population-based prospective cohort study which recruited 15,792 individuals aged 45-64 years between 1987 and 1989. In a sub-analysis undertaken in 10,872 participants who did not have gout prior to baseline, 274 people developed gout over the nine-year follow-up period [46]. Those who fulfilled an unspecified definition of "high" alcohol intake had twice the risk of incident gout, adjusted for sex, race, BMI, alcohol intake, and estimated glomerular filtration rate. In a case-control study nested within the THIN primary care database study, 24,768 people with incident gout were compared to 50,000 control subjects without gout who were frequency-matched for age, gender and calendar year [25]. There was a dose-response relationship between incident gout and prior alcohol consumption. Compared with those who did not drink alcohol, the multivariate ORs of incident gout in those drinking 1-9, 10-24, 25-42 and >42 units of alcohol per week were 1.06 (95\%CI $1.01,1.11), 1.56$ (95\%CI 1.49, 1.65), 2.45 (95\% CI 2.27, 2.63) and 3.00 (95\% CI 2.66, 3.38) respectively, adjusting for age, calendar year, GP visits, BMI, ischaemic heart disease, hypertension, hyperlipidemia, diabetes, chronic renal failure and use of diuretics ( 1 unit = $10 \mathrm{mls}$ of pure ethanol or $8 \mathrm{~g}$ of alcohol). In the HPFS, increasing alcohol intake was associated with increasing risk of incident gout [47]. Compared with men who did not drink 
alcohol, the multivariate RRs were $1.09(95 \%$ CI $0.85,1.40)$ for daily alcohol consumption $0.1-4.9 \mathrm{~g}, 1.25$ (95\% CI $0.95,1.64)$ for $5.0-9.9 \mathrm{~g}, 1.32$ (95\%CI 0.99, 1.75) for 10.0-14.9g, $1.49(95 \% \mathrm{CI} 1.14,1.94)$ for $15.0-29.9 \mathrm{~g}, 1.96(95 \% \mathrm{CI} 1.48,2.60)$ for $30.0-49.9 \mathrm{~g}$, and 2.53 $(95 \% \mathrm{CI} 1.73,3.70)$ for $250 \mathrm{~g}$. The multivariate RR per $10 \mathrm{~g}$ increase in daily alcohol consumption was 1.17 (95\% CI 1.11, 1.22). Compared to men drinking each type of drink less than once per month, those imbibing $\geq 2$ drinks per day had 2.5 times the risk of incident gout for beer, 1.6 times for spirits and no increased risk associated with wine (Table 3 ). The multivariate RR per serving per day was 1.49 (95\% CI 1.32, 1.70) for beer, $1.15(95 \% \mathrm{CI}$ $1.04,1.28)$ for spirits and $1.04(95 \%$ CI $0.88,1.22)$ for wine. The Framingham Heart Study has shown excessive alcohol consumption to be an independent risk for gout in both women and men [23]. Women who drank $\geq 7 \mathrm{oz}$ of alcohol per week had over three times the risk of incident gout and men drinking this amount over twice the risk, compared to those who drank less than 0-1oz per week (Table 3). Moderate consumption (2-6oz per week) was not associated with incident gout in either gender. In the internet-based case-crossover study described above [48], alcohol consumption was found to trigger recurrent gout attacks (multivariate OR 2.5; 95\% CI 1.1, 5.9; $\geq 7$ alcoholic drinks consumed in the previous two days, compared with no consumption; adjusted for purine intake and diuretic use).

\section{Obesity and the metabolic syndrome}

Gout is very commonly associated with comorbidity, including the metabolic syndrome. In a large cross-sectional study undertaken in NHANES-III, the prevalence of the metabolic syndrome in people with gout was $62.8 \%$ compared with $25.4 \%$ amongst people without gout (odds ratio (OR) 3.05; 95\% CI 2.01, 4.61; adjusted for age and gender) [49].

Several individual components of the metabolic syndrome have been shown to be independent risk factors for the development of gout (Table 4). A dose-dependent effect between increasing BMI and risk of incident gout has been demonstrated in several large prospective epidemiological studies. In the THIN database case-control study, individuals with a BMI between $25-29 \mathrm{~kg} / \mathrm{m}^{2}$ had an multivariate OR of $1.62(95 \%$ CI $1.55,1.70)$ for incident gout and those with BMI of $330 \mathrm{~kg} / \mathrm{m}^{2}$ an OR of 2.34 (95\% CI 2.22, 2.47) compared to those with a BMI $20-24 \mathrm{~kg} / \mathrm{m}^{2}$ [25]. In the HPFS, compared to those with a BMI 21$22.9 \mathrm{~kg} / \mathrm{m}^{2}$, the multivariate RR of incident gout in men was 0.85 in those with a BMI $<21 \mathrm{~kg} / \mathrm{m}^{2}$, increasing to 1.40 with BMI $23-24.9 \mathrm{~kg} / \mathrm{m}^{2}, 1.95$ with BMI $25-29.9 \mathrm{~kg} / \mathrm{m}^{2}, 2.33$ with BMI 30-34.9kg/m ${ }^{2}$ and 2.97 with BMI $\geq 35 \mathrm{~kg} / \mathrm{m}^{2}$ [50]. Furthermore, risk of incident gout was increased in men who had gained 20-29lbs (multivariate RR1.57; 95\%CI 1.15, 2.14 ) and $230 \mathrm{lbs}$ (RR 2.47; 95\% CI 1.86, 3.28) in weight since the age of 21 years compared with those whose weight was stable. In contrast, weight loss of 10lbs or more since baseline reduced the risk of incident gout by $39 \%$ (multivariate RR $0.61 ; 95 \%$ CI $0.40,0.92$ ).

An analysis undertaken in the ARIC study provides similar data for women (Table 4) [51]. A total of 6,263 women aged 45-64 years with no history of gout prior to baseline were followed-up for 9 years, identifying 106 cases of incident gout. Compared to women with a $\mathrm{BMI}<25 \mathrm{~kg} / \mathrm{m}^{2}$ at baseline, the adjusted RR of incident gout was $1.63(95 \% \mathrm{CI} 0.84,3.18)$ with a BMI $25-29.9 \mathrm{~kg} / \mathrm{m}^{2}, 2.76(95 \%$ CI $1.40,5.44)$ with a BMI $30-34.9 \mathrm{~kg} / \mathrm{m}^{2}$, and 3.90 $(95 \%$ CI $1.95,7.82)$ with a BMI $235 \mathrm{~kg} / \mathrm{m}^{2}$. In women with BMI $25-29.9 \mathrm{~kg} / \mathrm{m}^{2}$ and BMI 
$330 \mathrm{~kg} / \mathrm{m}^{2}$ at age 25 years, the multivariate RRs for incident gout were 3.36 (95\%CI 2.09, $5.41)$ and $2.84(1.33,6.09)$ respectively, compared to those with BMI $<25 \mathrm{~kg} / \mathrm{m}^{2}$ at age 25 years. Women with the highest tertile of weight gain ( $\geq 16.3 \mathrm{~kg}$ ) from age 25 years to baseline had twice the risk of incident gout compared with individuals in the lowest tertile (multivariate RR 2.05; 95\%CI 1.06, 3.96).

Evidence of a dose-dependent effect of increasing BMI on risk of incident gout in men and women is provided by the Framingham Heart Study (Table 4) [23]. Compared to those with a BMI $<25 \mathrm{~kg} / \mathrm{m}^{2}$, the multivariate RR of incident gout was $1.44(95 \% \mathrm{CI} 0.88,2.37)$ in women with a BMI $25-29.9 \mathrm{~kg} / \mathrm{m}^{2}$, rising to $2.74(95 \%$ CI $1.65,4.58)$ in those with a $\mathrm{BMI} \geq 30 \mathrm{~kg} / \mathrm{m}^{2}$. In men, the corresponding RRs were 1.76 (95\%CI 1.22, 2.54) and 2.90 $(95 \%$ CI $1.89,4.44)$ respectively. Increasing BMI has also been found to be an independent risk factor for gout flare in the THIN database (BMI $15-19 \mathrm{~kg} / \mathrm{m}^{2}$, men hazards ratio (HR) 0.77, women 0.79; BMI 25-29kg/m², men HR 1.07, women 1.10 ; BMI $\geq 30 \mathrm{~kg} / \mathrm{m}^{2}$, men 1.12 , women 1.43) compared to those with a BMI in the range $20-24 \mathrm{~kg} / \mathrm{m}^{2}$ [52].

Several large prospective epidemiological studies have examined the association between hypertension and gout (Table 4). Hypertension was found to be an independent risk factor for incident gout in the THIN database case-control study although the magnitude of increased risk was small [25]. In contrast, in both HPFS and ARIC, the risk of incident gout in those with hypertension was twice that of those without hypertension [46,50]. The findings of two studies suggest that hypertension has a greater effect on risk of incident gout in women than men. In the Framingham Heart Study, the multivariate RR of incident gout associated with hypertension was 1.59 (95\% 1.12, 2.24) in men and 1.82 (95\% CI 1.06, 3.14) in women, although there was considerable overlap of the confidence intervals [23]. However, in the THIN database, narrower confidence intervals suggest that hypertension has a greater influence on gout flares in women (multivariate RR $1.45 ; 95 \% \mathrm{CI} 1.30,1.62$ ) than men (RR 1.08; 95\%CI 1.02, 1.13) [52].

Although hyperglycaemia and insulin resistance are recognised components of the metabolic syndrome, the role of diabetes mellitus as a risk factor for the development for gout has received relatively little attention. Interestingly, in the THIN database case-control study, individuals with diabetes had a 33\% lower risk of developing gout than those without diabetes (multivariate RR $0.67 ; 95 \%$ CI $0.63,0.71$ ) [53]. This finding was more marked in men than women (Table 4). The risk of developing gout reduced with increasing duration of diabetes: duration 0-3 years RR 0.81 (95\% CI 0.74, 0.90), 4-9 years RR 0.67 (95\%CI 0.61, $0.73)$, and 10 years or longer RR 0.52 (95\%CI $0.46,0.58)$. Risk was also less with type I than type II diabetes (Table 4). Although these findings may seem counter-intuitive, the predisposition to hyperuricaemia and gout induced by hyperinsulinaemia and insulin resistance in the pre-diabetic state is thought to be reversed by the uricosuric effects of glycosuria once frank diabetes develops [54-56].

A less well-established putative risk factor for gout is obstructive sleep apnoea which is commonly associated with both components of the metabolic syndrome and hyperuricaemia [57-59]. Hypoxia enhances nucleotide turnover thereby generating purines which are metabolised to uric acid $[60,61]$, providing a biologically plausible mechanism by which 
obstructive sleep apnoea might predispose to gout. In a small cross-sectional study undertaken in a GP consultation database, gout was associated with sleep disorders (OR $1.39 ; 95 \%$ CI 1.06, 1.81; adjusted for age, gender, practice, diabetes, hypertension, diuretic use and ischaemic heart disease) [62].There was no association with obstructive sleep apnoea although the study was under-powered. Larger prospective epidemiological studies are required to examine this proposed association in more detail.

\section{Medications}

A number of medications and substances have been implicated in the aetiology of gout [63], however, diuretics have received the greatest attention. A recent systematic review examined the risk of gouty arthritis in patients using diuretics [64], identifying two RCTs and 11 epidemiologic studies. In one RCT, the rate ratio of gout for use of bendrofluazide vs placebo was 11.8, whereas the other RCT found a rate ratio of 6.3 for use of hydrochlorothiazide plus triamterene vs placebo. Three cohort studies $[28,50,65]$ and four case-control studies [66-69] found an increased of gout in diuretic users. The two largest cohort studies identified by this systematic review adjusted for medications [65], comorbidities [50,65] and life-style factors [50] finding RRs of 1.77 for incident gout in the HPFS (95\%CI 1.42, 2.20) [50] and 1.99 for initiation of anti-gout medication (95\%CI 1.21, 3.26) [65]. The Framingham Heart Study was not included in this review but reported multivariate RRs for diuretic use of 2.39 (95\% CI 1.53, 3.74) in women and 3.41 (95\%CI $2.38,4.89)$ in men [23]. In the THIN case-control study, the RR for incident gout amongst those currently using diuretics was $2.36(95 \% \mathrm{CI} 2.21,2.52)$ in people with hypertension and $3.01(95 \%$ CI 2.72, 3.33) amongst those without hypertension, after adjustment for GP visits, BMI, alcohol use, ischaemic heart disease, hypertension, hyperlipidaemia, renal failure, and use of other anti-hypertensive drugs [70]. Furthermore, amongst current diuretic users, the risk of developing gout increased with both the duration of diuretic therapy and increased dosage, providing evidence of a dose-dependent effect. Finally, the aforementioned internetbased case-crossover study has also showed consistent findings for the risk of recurrent gout [67]. These studies collectively confirm the well-recognized clinical entity of diureticinduced gout, also known as secondary gout.

Aspirin has long-been recognised to have effects on renal tubular urate handling. In the 1950s, high-dose aspirin was found to be uricosuric whilst low-doses were urate-retaining [71]. However, only very recently has epidemiological evidence of the clinical significance of this association come to light. In the internet-based case-crossover study, use of low-dose aspirin ( $\$ 25 \mathrm{mg} /$ day) in the prior two consecutive days was associated with an increased risk of recurrent gout attacks (OR 1.81; 95\% CI 1.30, 2.51) [72]. Interestingly, concurrent use of allopurinol removed the increased risk of recurrent gout attacks associated with lowdose aspirin (adjusted OR 0.89; 95\%CI 0.55, 1.44) suggesting that urate-lowering therapy may mitigate the risk of recurrent acute gout exacerbated by use of low-dose aspirin.

Several classes of anti-hypertensive drugs are known to influence serum urate levels. Bblockers increase serum urate levels whereas both calcium-channel blockers and losartan have urate-lowering properties [63,73]. In addition to examining the risk of gout associated with diuretic use, the THIN primary care database case-control study described above also 
investigated the risk of incident gout conferred by a wide-range of anti-hypertensive drugs including calcium-channel blockers, losartan, $\beta$-blockers, angiotensin-converting-enzyme (ACE) inhibitors, and non-losartan angiotensin-II (AII) receptor blockers [70]. Amongst those with hypertension, current use of $\beta$-blockers (RR 1.48; 95\%CI 1.40, 1.57), ACEinhibitors (RR 1.24; 95\%CI 1.17, 1.32), and non-losartan AII-receptor blockers (RR 1.29; 95\% CI 1.16, 1.43) was more common in those with incident gout whereas current use of calcium-channel blockers (RR 0.87; 95\%CI 0.82, 0.93) and losartan (RR 0.81; 95\%CI 0.70, 0.94) was less common.

\section{Renal Disease}

The association between gout and renal disease is complex and could be bi-directional, i.e. although renal disease predisposes to the development of gout, gout and its treatment are thought themselves to lead to renal impairment and chronic kidney disease. Such associations have been recognised for many years yet early studies were undertaken in specialist secondary care populations [74-76] which may not representative of the majority of patients with gout who are managed exclusively in primary care. More recently, two population-based epidemiological studies have provided convincing evidence that renal disease is a risk factor for gout. In the HPFS, the multivariate RR of incident gout in men with chronic renal failure compared to those without chronic renal failure was 3.61 (95\% CI $1.60,8.14)$ [50]. In the THIN case-control study, prior history of chronic renal failure was strongly associated with incident gout (OR 2.48; 95\% CI 2.19, 2.81) [25]. Renal failure was also associated with risk of gout flare (HR 1.33; 95\%CI 1.20, 1.48) [52]. Furthermore, in the ARIC study, participants with a low estimated glomerular filtration rate $(<60 \mathrm{ml} / \mathrm{min})$ had twice the risk of incident gout as those with a normal estimated glomerular filtration rate (>90 $\mathrm{ml} / \mathrm{min}$ ) (multivariate HR 2.43; 95\%CI 1.50, 3.94) [46].

\section{Osteoarthritis}

Although hyperuricaemia is a very strong risk factor for gout, many hyperuricaemic individuals do not develop gout. It is not fully understood why some people with hyperuricaemia appear to form and deposit MSU crystals more readily than others, however, it is thought that MSU crystals may deposit more easily in osteoarthritic cartilage [77]. This hypothesis has also been suggested to explain the striking predilection of gout for the first metatarsophalangeal joint, which is also a target joint for OA [78]. Both radiographic and clinical cross-sectional studies have shown that attacks of gout occur at joints already affected by OA. A hospital-based study of 262 subjects with gout found a significant correlation between the occurrence of acute attacks of gout and radiographic OA at the first MTP joints, tarsal joints and knees [79]. More recently, a community-based study of 164 subjects with gout found a strong association between sites of acute attacks of gout and the presence of clinical OA (multivariate OR 7.94; 95\%CI 6.27, 10.05), adjusted for age, gender, BMI and diuretic use [80]. However, nodal OA was no more frequent in gout subjects than in 656 control subjects without gout [81]. Such cross-sectional studies cannot determine causality or temporal aspects of this association, hence further prospective studies are required.

Rheum Dis Clin North Am. Author manuscript; available in PMC 2015 May 01. 


\section{Conclusion}

A number of epidemiological studies from a diverse range of countries suggest that gout has increased in prevalence over the last few decades, making it the most common inflammatory arthritis, particularly among men. Incidence data are scarce; however, the Rochester Epidemiology Project found that the incidence of gout without diuretic exposure has doubled in the US between the 1970s and 1990s. Evidence from prospective epidemiological studies has confirmed purported dietary factors, obesity, the metabolic syndrome, hypertension, use of diuretics, and chronic kidney disease as clinically relevant risk factors for hyperuricemia and gout, whereas low-fat dairy products, coffee, and vitamin $\mathrm{C}$ appear to be protective against these conditions. Furthermore, the use of $\beta$-blockers and angiotension-II receptor antagonists (other than losartan) are independent risk factors for the development of hyperuricemia and gout, whereas calcium-channel blockers and losartan appear to reduce the risk of developing these conditions. Whilst further prospective studies are necessary to explore putative risk factors such as obstructive sleep apnoea, OA, and more novel observations concerning anti-hypertensive medications in more depth, the immediate challenge is to translate the key findings of these epidemiological observations into simple messages to improve the prevention and management of this prevalent but often under-treated condition.

\section{References}

1. Chandratre P, Roddy E, Clarson L, et al. Health-related quality of life in gout: a systematic review. Rheumatology (Oxford). 2013 [Epub ahead of print].

2. Lawrence RC, Hochberg MC, Kelsey JL, et al. Estimates of the prevalence of selected arthritic and musculoskeletal diseases in the United States. J Rheumatol. 1989; 16:427-441. [PubMed: 2746583]

3. Lawrence RC, Helmick CG, Arnett FC, et al. Estimates of the prevalence of arthritis and selected musculoskeletal disorders in the United States. Arthritis Rheum. 1998; 41:778-799. [PubMed: 9588729]

4. Lawrence RC, Felson DT, Helmick CG, et al. Estimates of the prevalence of arthritis and other rheumatic conditions in the United States. Part II. Arthritis Rheum. 2008; 58:26-35. [PubMed: 18163497]

5. Juraschek SP, Miller ER 3rd, Gelber AC. Body mass index, obesity, and prevalent gout in the United States in 1988-1994 and 2007-2010. Arthritis Care Res (Hoboken). 2013; 65:127-132. [PubMed: 22778033]

6. Zhu Y, Pandya BJ, Choi HK. Prevalence of gout and hyperuricemia in the US general population: the National Health and Nutrition Examination Survey 2007-2008. Arthritis Rheum. 2011; 63:3136-3141. [PubMed: 21800283]

7. Wallace KL, Riedel AA, Joseph-Ridge N, et al. Increasing prevalence of gout and hyperuricemia over 10 years among older adults in a managed care population. J Rheumatol. 2004; 31:1582-1587. [PubMed: 15290739]

8. Currie WJ. Prevalence and incidence of the diagnosis of gout in Great Britain. Ann Rheum Dis. 1979; 38:101-106. [PubMed: 312625]

9. Steven MM. Prevalence of chronic arthritis in four geographical areas of the Scottish Highlands. Ann Rheum Dis. 1992; 51:186-194. [PubMed: 1550402]

10. Harris CM, Lloyd DC, Lewis J. The prevalence and prophylaxis of gout in England. J Clin Epidemiol. 1995; 48:1153-1158. [PubMed: 7636517]

11. Mikuls TR, Farrar JT, Bilker WB, et al. Gout epidemiology: results from the UK General Practice Research Database, 1990-1999. Ann Rheum Dis. 2005; 64:267-272. [PubMed: 15647434] 
12. Annemans L, Spaepen E, Gaskin M, et al. Gout in the UK and Germany: prevalence, comorbidities and management in general practice 2000-2005. Ann Rheum Dis. 2008; 67:960-966. [PubMed: 17981913]

13. Elliot AJ, Cross KW, Fleming DM. Seasonality and trends in the incidence and prevalence of gout in England and Wales 1994-2007. Ann Rheum Dis. 2009; 68:1728-1733. [PubMed: 19029167]

14. Lennane GAQ, Rose BS, Isdale IC. Gout in the Maori. Ann Rheum Dis. 1960; 19:120-125. [PubMed: 14415696]

15. Prior IA, Rose BS. Uric acid, gout and public health in the South Pacific. NZ Med J. 1966; 65:295-300.

16. Klemp P, Stansfield SA, Castle B, et al. Gout is on the increase in New Zealand. Ann Rheum Dis. 1997; 56:22-26. [PubMed: 9059136]

17. Winnard D, Wright C, Jackson G, et al. Gout, diabetes and cardiovascular disease in the Aotearoa New Zealand adult population: co-prevalence and implications for clinical practice. NZ Med J. 2012; 126:53-64.

18. Nan H, Qiao Q, Dong Y, et al. The prevalence of hyperuricemia in a population of the coastal city of Qingdao, China. J Rheumatol. 2006; 33:1346-1350. [PubMed: 16821269]

19. Miao Z, Li C, Chen Y, et al. Dietary and lifestyle changes associated with high prevalence of hyperuricaemia and gout in the Shandong coastal cities of Eastern China. J Rheumatol. 2008; 35:1859-1864. [PubMed: 18634142]

20. Roubenoff R, Klag MJ, Mead LA, et al. Incidence and risk factors for gout in white men. JAMA. 1991; 266:3004-3007. [PubMed: 1820473]

21. Choi HK, Atkinson K, Karlson EW, et al. Purine-rich foods, dairy and protein intake, and the risk of gout in men. N Engl J Med. 2004; 350:1093-1103. [PubMed: 15014182]

22. Wallace SL, Robinson H, Masi AT, et al. Preliminary criteria for the classification of the acute arthritis of primary gout. Arthritis Rheum. 1977; 20:895-900. [PubMed: 856219]

23. Bhole V, de Vera M, Rahman MM, et al. Epidemiology of gout in women: fifty-two-year followup of a prospective cohort. Arthritis Rheum. 2010; 62:1069-1076. [PubMed: 20131266]

24. Arromdee E, Michet CJ, Crowson CS, et al. Epidemiology of gout: is the incidence rising? J Rheumatol. 2002; 29:2403-2406. [PubMed: 12415600]

25. Cea, Soriano L.; Rothenbacher, D.; Choi, HK., et al. Contemporary epidemiology of gout in the UK general population. Arthritis Res Ther. 2011; 13:R39. [PubMed: 21371293]

26. Campion EW, Glynn RJ, DeLabry LO. Asymptomatic hyperuricemia. Risks and consequences in the Normative Aging Study. Am J Med. 1987; 82:421-426. [PubMed: 3826098]

27. Trifirò G, Morabito $\mathrm{P}$, Cavagna L. Epidemiology of gout and hyperuricaemia in Italy during the years 2005-2009: a nationwide population-based study. Ann Rheum Dis. 2013; 72:694-700. [PubMed: 22736095]

28. Lin KC, Lin HY, Chou P. The interaction between uric acid level and other risk factors on the development of gout among asymptomatic hyperuricemic men in a prospective study. $\mathrm{J}$ Rheumatol. 2000; 27:1501-1505. [PubMed: 10852278]

29. Dalbeth N, Wong S, Gamble GD, et al. Acute effect of milk on serum urate concentrations: a randomised controlled crossover trial. Ann Rheum Dis. 2010; 69:1677-82. [PubMed: 20472590]

30. Garrel DR, Verdy M, PetitClerc C, et al. Milk- and soy-protein ingestion: acute effect on serum uric acid concentration. Am J Clin Nutr. 1991; 53:665-669. [PubMed: 2000819]

31. Dalbeth N, Ames R, Gamble GD, et al. Effects of skim milk powder enriched with glycomacropeptide and G600 milk fat extract on frequency of gout flares: a proof-of-concept randomised controlled trial. Ann Rheum Dis. 2012; 71:929-934. [PubMed: 22275296]

32. Zhang Y, Chen C, Choi H, et al. Purine-rich foods intake and recurrent gout attacks. Ann Rheum Dis. 2012; 71:1448-1453. [PubMed: 22648933]

33. Bruce CR, Carey AL, Hawley JA, et al. Intramuscular heat shock protein 72 and heme oxygenase- 1 mRNA are reduced in patients with type 2 diabetes: evidence that insulin resistance is associated with a disturbed antioxidant defense mechanism. Diabetes. 2003; 52:2338-2345. [PubMed: 12941774] 
34. Thirunavukkarasu V, Anuradha CV. Influence of a-lipoic acid on lipid peroxidation and antioxidant defence system in blood of insulin-resistant rats. Diabetes Obes Metab. 2004; 6:200207. [PubMed: 15056128]

35. Ter Maaten JC, Voorburg A, Heine RJ, et al. Renal handling of urate and sodium during acute physiological hyperinsulinaemia in healthy subjects. Clin Sci (Lond). 1997; 92:51-58. [PubMed: 9038591]

36. Kela U, Vijayvargiya R, Trivedi CP. Inhibitory effects of methylxanthines on the activity of xanthine oxidase. Life Sci. 1980; 27:2109-2119. [PubMed: 6894176]

37. Choi HK, Willett W, Curhan G. Coffee consumption and risk of incident gout in men: a prospective study. Arthritis Rheum. 2007; 56:2049-2055. [PubMed: 17530645]

38. Choi HK, Curhan G. Coffee consumption and risk of incident gout in women: the Nurses' Health Study. Am J Clin Nutr. 2010; 92:922-927. [PubMed: 20739424]

39. Raivio KO, Becker A, Meyer LJ, et al. Stimulation of human purine synthesis de novo by fructose infusion. Metabolism. 1975; 24:861-869. [PubMed: 166270]

40. Choi HK, Curhan G. Soft drinks, fructose consumption, and the risk of gout in men: prospective cohort study. BMJ. 2008; 336:309-312. [PubMed: 18244959]

41. Choi HK, Willett W, Curhan G. Fructose-rich beverages and risk of gout in women. JAMA. 2010; 304:2270-2278. [PubMed: 21068145]

42. Juraschek SP, Miller ER 3rd, Gelber AC. Effect of oral vitamin C supplementation on serum uric acid: a meta-analysis of randomized controlled trials. Arthritis Care Res (Hoboken). 2011; 63:1295-1306. [PubMed: 21671418]

43. Choi HK, Gao X, Curhan G. Vitamin C intake and the risk of gout in men: a prospective study. Arch Intern Med. 2009; 169:502-507. [PubMed: 19273781]

44. Zhang Y, Neogi T, Chen C, et al. Cherry consumption and decreased risk of recurrent gout attacks. Arthritis Rheum. 2012; 64:4004-4011. [PubMed: 23023818]

45. Fam AG. Gout, diet, and the insulin resistance syndrome. J Rheumatol. 2002; 29:1350-1355. [PubMed: 12136887]

46. McAdams-DeMarco MA, Maynard JW, et al. Hypertension and the risk of incident gout in a population-based study: the atherosclerosis risk in communities cohort. J Clin Hypertens (Greenwich). 2012; 14:675-679. [PubMed: 23031144]

47. Choi HK, Atkinson K, Karlson EW, et al. Alcohol intake and risk of incident gout in men: a prospective study. Lancet. 2004; 363:1277-1281. [PubMed: 15094272]

48. Zhang Y, Woods R, Chaisson CE, et al. Alcohol consumption as a trigger of recurrent gout attacks. Am J Med. 2006; 119:800-808. [PubMed: 16945617]

49. Choi HK, Ford ES, Li C, et al. Prevalence of the metabolic syndrome in patients with gout: the Third National Health and Nutrition Examination Survey. Arthritis Rheum. 2007; 57:109-115. [PubMed: 17266099]

50. Choi HK, Atkinson K, Karlson EW, et al. Obesity, weight change, hypertension, diuretic use, and risk of gout in men: the health professionals follow-up study. Arch Intern Med. 2005; 165:742748. [PubMed: 15824292]

51. Maynard JW, McAdams DeMarco MA, Baer AN, et al. Incident gout in women and association with obesity in the Atherosclerosis Risk in Communities (ARIC) Study. Am J Med. 2012; 125:717.e9-717.e17. [PubMed: 22571781]

52. Rothenbacher D, Primatesta P, Ferreira A, et al. Frequency and risk factors of gout flares in a large population-based cohort of incident gout. Rheumatology (Oxford). 2011; 50:973-981. [PubMed: 21228059]

53. Rodríguez G, Soriano LC, Choi HK. Impact of diabetes against the future risk of developing gout. Ann Rheum Dis. 2010; 69:2090-2094. [PubMed: 20570836]

54. Herman JB, Goldbourt U. Uric acid and diabetes: observations in a population study. Lancet. 1982; 2:240-243. [PubMed: 6124672]

55. Choi HK, Ford ES. Haemoglobin A1c, fasting glucose, serum C-peptide and insulin resistance in relation to serum uric acid levels--the Third National Health and Nutrition Examination Survey. Rheumatology (Oxford). 2008; 47:713-717. [PubMed: 18390895] 
56. Cook DG, Shaper AG, Thelle DS, et al. Serum uric acid, serum glucose and diabetes: relationships in a population study. Postgrad Med J. 1986; 62:1001-1006. [PubMed: 3628142]

57. Parish JM, Adam T, Facchiano L. Relationship of metabolic syndrome and obstructive sleep apnea. J Clin Sleep Med. 2007; 3:467-472. [PubMed: 17803009]

58. Kono M, Tatsumi K, Saibara T, et al. Obstructive sleep apnea syndrome is associated with some components of metabolic syndrome. Chest. 2007; 131:1387-1392. [PubMed: 17494788]

59. Ruiz García A, Sánchez Armengol A, Luque Crespo E, et al. Blood uric acid levels in patients with sleep-disordered breathing. Arch Bronconeumol. 2006; 42:492-500. [PubMed: 17067515]

60. Glantzounis GK, Tsimoyiannis EC, Kappas AM, et al. Uric acid and oxidative stress. Curr Pharm Des. 2005; 11:4145-1451. [PubMed: 16375736]

61. Hasday JD, Grum CM. Nocturnal increase of urinary uric acid:creatinine ratio. A biochemical correlate of sleep-associated hypoxemia. Am Rev Respir Dis. 1987; 135:534-538. [PubMed: 3826879]

62. Roddy E, Muller S, Hayward R, et al. The association of gout with sleep disorders: a crosssectional study in primary care. BMC Musculoskelet Disord. 2013; 14:119. [PubMed: 23557073]

63. Choi HK, Mount DB, Reginato AM, et al. Pathogenesis of gout. Ann Intern Med. 2005; 143:499_ 516. [PubMed: 16204163]

64. Hueskes BA, Roovers EA, Mantel-Teeuwisse AK, et al. Use of diuretics and the risk of gouty arthritis: a systematic review. Semin Arthritis Rheum. 2012; 41:879-889. [PubMed: 22221907]

65. Gurwitz JH, Kalish SC, Bohn RL, et al. Thiazide diuretics and the initiation of anti-gout therapy. J Clin Epidemiol. 1997; 50:953-959. [PubMed: 9291881]

66. Hanly JG, Skedgel C, Sketris I, et al. Gout in the elderly - a population health study. J Rheumatol. 2009; 36:822-830. [PubMed: 19286852]

67. Hunter DJ, York M, Chaisson CE, et al. Recent diuretic use and the risk of recurrent gout attacks: the online case-crossover gout study. J Rheumatol. 2006; 33:1341-1345. [PubMed: 16758506]

68. Stamp L, Ha L, Searle M, et al. Gout in renal transplant recipients. Nephrology (Carlton). 2006; 11:367-371. [PubMed: 16889578]

69. Suppiah R, Dissanayake A, Dalbeth N. High prevalence of gout in patients with Type 2 diabetes: male sex, renal impairment, and diuretic use are major risk factors. NZ Med J. 2008; 121:43-50.

70. Choi HK, Soriano LC, Zhang Y, et al. Antihypertensive drugs and risk of incident gout among patients with hypertension: population based case-control study. BMJ. 2012; 344:d8190. [PubMed: 22240117]

71. Yü TF, Gutman AB. Study of the paradoxical effects of salicylate in low, intermediate and high dosage on the renal mechanisms for excretion of urate in man. J Clin Invest. 1959; 38:1298-1315. [PubMed: 13673086]

72. Zhang Y, Neogi T, Chen C, et al. Low-dose aspirin use and recurrent gout attacks. Ann Rheum Dis. Jan 23.2013 [Epub ahead of print].

73. Reyes AJ. Cardiovascular drugs and serum uric acid. Cardiovasc Drugs Ther. 2003; 17:397-414. [PubMed: 15107595]

74. Berger L, Yü TF. Renal function in gout. IV. An analysis of 524 gouty subjects including longterm follow-up studies. Am J Med. 1975; 59:605-613. [PubMed: 1200033]

75. Fessel WJ. Renal outcomes of gout and hyperuricemia. Am J Med. 1979; 67:74-82. [PubMed: 463920]

76. Yü TF, Berger L. Impaired renal function in gout. Its association with hypertensive vascular disease and intrinsic renal disease. Am J Med. 1982; 72:95-100. [PubMed: 7058827]

77. Roddy E, Doherty M. Gout and osteoarthritis: a pathogenetic link? Joint Bone Spine. 2012; 79:425-427. [PubMed: 22867976]

78. Roddy E. Revisiting the pathogenesis of podagra: why does gout target the foot? J Foot Ankle Res. 2011; 4:13. [PubMed: 21569453]

79. Kawenoki-Minc E, Eyman E, Leo W, et al. Osteoarthrosis and spondylosis in gouty patients. Analysis of 262 cases of gout. Reumatologia. 1974; 12:267-277. [PubMed: 4410296]

80. Roddy E, Zhang W, Doherty M. Are joints affected by gout also affected by osteoarthritis? Ann Rheum Dis. 2007; 66:1374-1377. [PubMed: 17284542] 
81. Roddy E, Zhang W, Doherty M. Gout and nodal osteoarthritis: a case-control study. Rheumatology. 2008; 7:732-733. [PubMed: 18356175] 


\section{Key points}

- Gout has become more prevalent over the past few decades, affecting over 3\% of adults in the US. The limited incidence data in the US suggest a similarly increasing trend.

- Excessive consumption of meat, seafood, sugar-sweetened soft drinks, fructose and alcohol increase the risk of developing hyperuricemia and gout, whereas low-fat dairy products, coffee, and vitamin $\mathrm{C}$ appear to be protective against these conditions.

- Obesity, hypertension, the metabolic syndrome, chronic renal failure, and use of diuretics, $\beta$-blockers and angiotension-II receptor antagonists (other than losartan) are independent risk factors for the development of hyperuricemia and gout whereas diabetes mellitus, calcium-channel blockers, and losartan appear to reduce the risk of developing these conditions. 


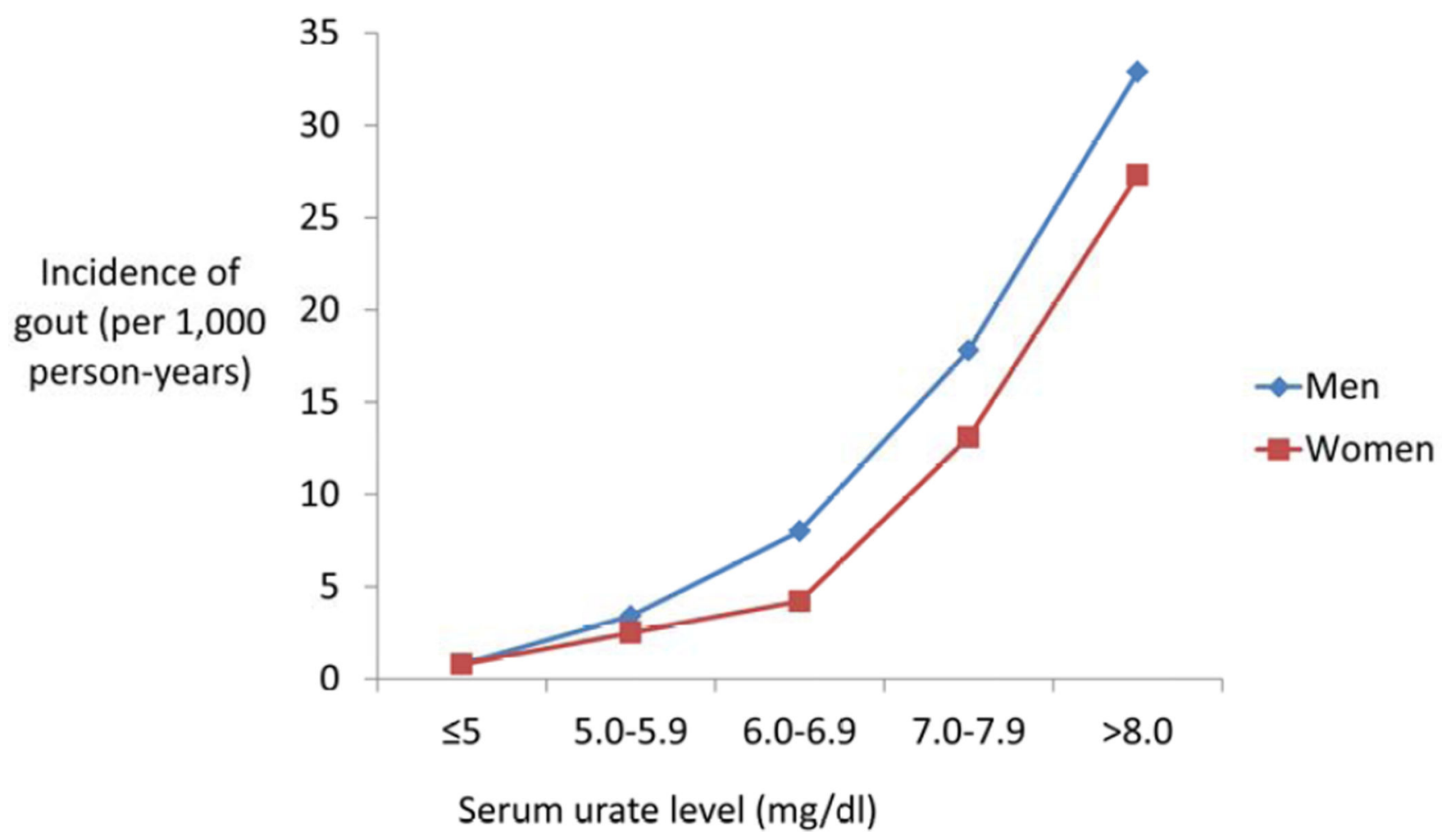

Figure 1. Increasing incidence of gout in men and women with serum urate level

Data from Bhole V, de Vera M, Rahman MM et al. Epidemiology of gout in women: fiftytwo-year followup of a prospective cohort. Arthritis Rheum 2010;62:1069-1076. 


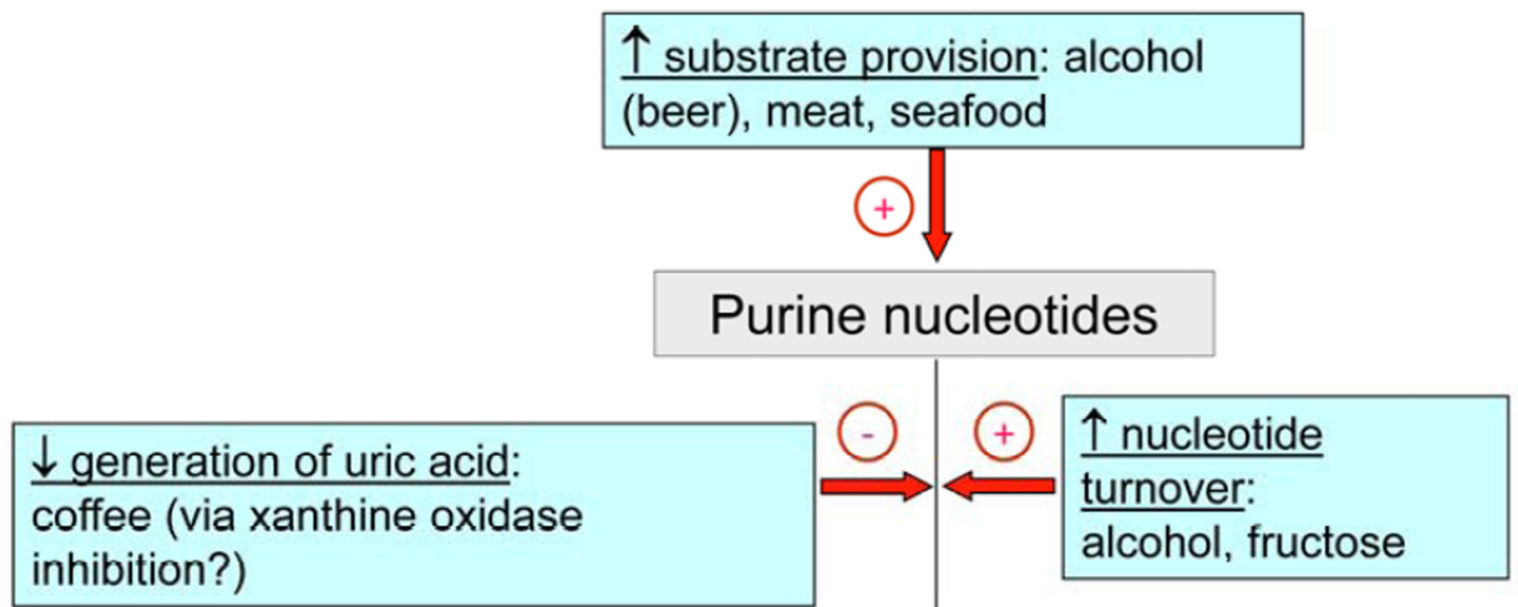

$\uparrow$ renal excretion: vitamin $\mathrm{C}$, dairy products, coffee (via $\downarrow$ insulin resistance), weight loss (via $\downarrow$ insulin resistance)

$\downarrow$ renal excretion:

alcohol (via lactic acidosis) obesity (via $\uparrow$ insulin resistance) fructose (via $\uparrow$ insulin resistance?)

Figure 2.

Proposed mechanism of action of lifestyle factors in the aetiology of hyperuricaemia and gout 


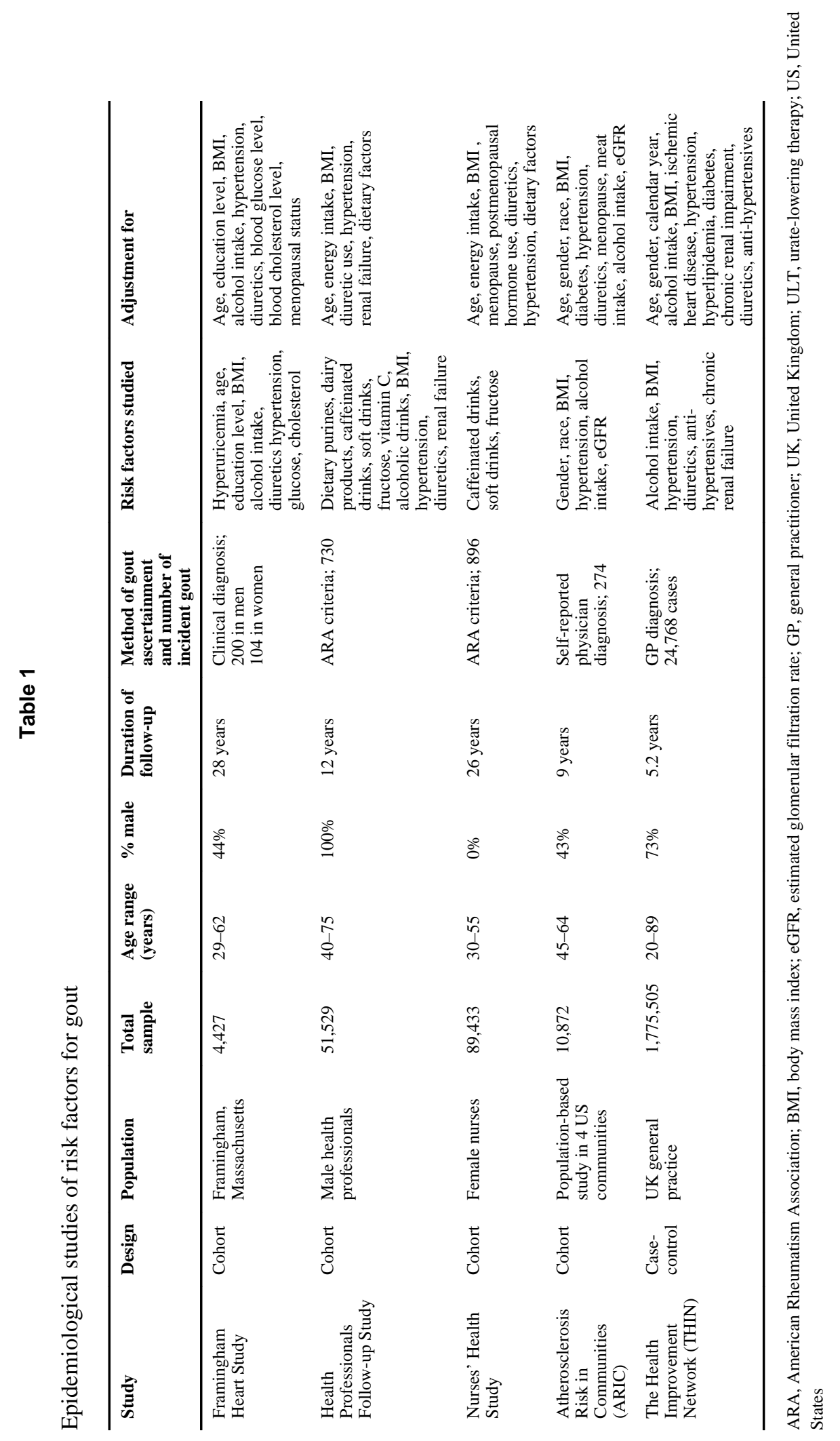

Rheum Dis Clin North Am. Author manuscript; available in PMC 2015 May 01. 


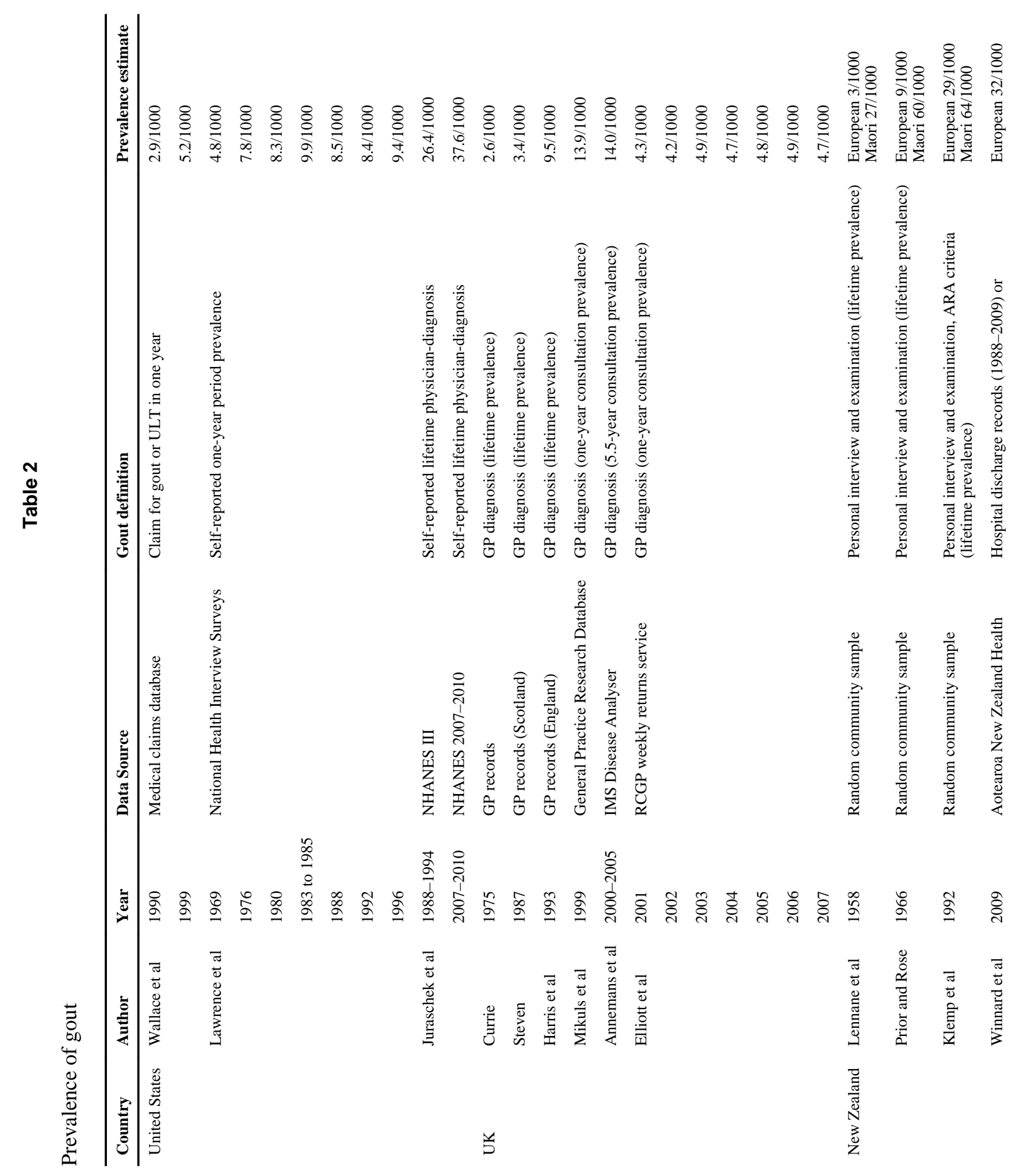

Rheum Dis Clin North Am. Author manuscript; available in PMC 2015 May 01. 


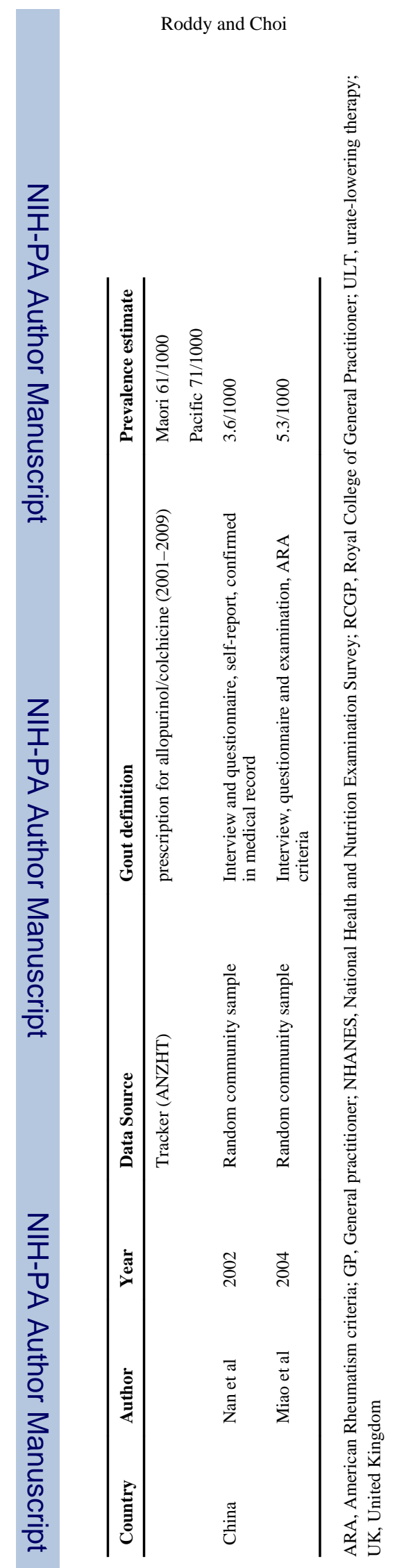

Rheum Dis Clin North Am. Author manuscript; available in PMC 2015 May 01. 


\section{Table 3}

Dietary factors and risk of incident gout

\begin{tabular}{|c|c|c|c|c|}
\hline Dietary factor & Study & Exposure group & Referent group & $\begin{array}{l}\text { Multivariate risk estimate } \\
\text { (95\% confidence interval) }\end{array}$ \\
\hline Total Meat & HPFS & Highest quintile & Lowest quintile & RR $1.41(1.07,1.86)$ \\
\hline Seafood & HPFS & Highest quintile & Lowest quintile & RR $1.51(1.17,1.95)$ \\
\hline Purine-rich vegetables & HPFS & Highest quintile & Lowest quintile & RR $0.96(0.79,1.19)$ \\
\hline Dairy products & HPFS & Highest quintile & Lowest quintile & RR $0.56(0.42,0.74)$ \\
\hline Low-fat dairy & HPFS & Highest quintile & Lowest quintile & RR $0.58(0.45,0.76)$ \\
\hline High-fat dairy & HPFS & Highest quintile & Lowest quintile & RR $1.00(0.77,1.29)$ \\
\hline \multirow[t]{2}{*}{ Coffee } & HPFS & $\Varangle 6$ cups/day & None & RR $0.41(0.19,0.88)$ \\
\hline & Nurses' Health Study & $\geq 4$ cups/day & None & RR $0.43(0.30,0.61)$ \\
\hline \multirow[t]{2}{*}{ Decaffeinated coffee } & HPFS & $\geq 4$ cups/day & None & RR $0.73(0.46,1.17)$ \\
\hline & Nurses' Health Study & $>1$ cups/day & None & RR $0.77(0.63,0.95)$ \\
\hline \multirow[t]{2}{*}{ Tea } & HPFS & $\geq 4$ cups/day & None & RR $0.82(0.38,1.75)$ \\
\hline & Nurses' Health Study & $\geq 4$ cups/day & None & RR $1.55(0.98,2.47)$ \\
\hline \multirow[t]{2}{*}{ Total caffeine } & HPFS & Highest quintile & Lowest quintile & RR $0.83(0.64,1.08)$ \\
\hline & Nurses' Health Study & Highest quintile & Lowest quintile & RR $0.52(0.41,0.68)$ \\
\hline \multirow[t]{2}{*}{ Sugar-sweetened soft drinks } & HPFS & $\geq 2$ servings/day & $<1$ serving/month & RR $1.85(1.08,3.16)$ \\
\hline & Nurses' Health Study & $\geq 2$ servings/day & $<1$ serving/month & RR $2.39(1.34,4.26)$ \\
\hline \multirow[t]{2}{*}{ Diet soft drinks } & HPFS & $\geq 2$ servings/day & $<1$ serving/month & RR $1.12(0.82,1.52)$ \\
\hline & Nurses’ Health Study & $\geq 2$ servings/day & $<1$ serving/month & RR $1.18(0.87,1.58)$ \\
\hline \multirow[t]{2}{*}{ Free fructose } & HPFS & Highest quintile & Lowest quintile & RR $2.02(1.49,2.75)$ \\
\hline & Nurses' Health Study & Highest quintile & Lowest quintile & RR $1.62(1.20,2.19)$ \\
\hline Vitamin C & HPFS & $>1500 \mathrm{mg} /$ day & $<250 \mathrm{mg} /$ day & RR $0.55(0.38,0.80)$ \\
\hline \multirow[t]{5}{*}{ Alcohol } & ARIC & "High" alcohol intake & Not defined & HR $2.00(1.42,2.82)$ \\
\hline & THIN & $>42$ units/week & None & OR $3.00(2.66,3.38)$ \\
\hline & HPFS & $>50 \mathrm{~g} /$ day & None & RR $2.53(1.73,3.70)$ \\
\hline & Framingham Heart (men) & $>7 \mathrm{oz} /$ week & $0-1$ oz/week & RR $2.21(1.56,3.14)$ \\
\hline & Framingham Heart (women) & $>7 \mathrm{oz} /$ week & $0-1$ oz/week & RR $3.10(1.69,5.68)$ \\
\hline Beer & HPFS & $>2$ servings/day & $<1$ serving/month & RR $2.51(1.77,3.55)$ \\
\hline Spirits & HPFS & $>2$ servings/day & $<1$ serving/month & RR $1.60(1.19,2.16)$ \\
\hline Wine & HPFS & $>2$ servings/day & $<1$ servingmonth & RR $1.05(0.64,1.72)$ \\
\hline
\end{tabular}

ARIC, Atherosclerosis Risk in Communities; HPFS, Health Professionals Follow-up Study; HR, hazards ratio; OR, odds ratio; RR, relative risk; THIN, The Health Improvement Network 
Table 4

Medical conditions and risk of incident gout

\begin{tabular}{|c|c|c|c|c|}
\hline Risk factor & Study & Exposure group & Referent group & $\begin{array}{l}\text { Multivariate risk } \\
\text { estimate (95\% } \\
\text { confidence interval) }\end{array}$ \\
\hline \multirow[t]{11}{*}{ BMI } & THIN & BMI $25-29 \mathrm{~kg} / \mathrm{m}^{2}$ & BMI $20-24 \mathrm{~kg} / \mathrm{m}^{2}$ & OR $1.62(1.55,1.70)$ \\
\hline & THIN & BMI $230 \mathrm{~kg} / \mathrm{m}^{2}$ & BMI $20-24 \mathrm{~kg} / \mathrm{m}^{2}$ & OR $2.34(2.22,2.47)$ \\
\hline & HPFS & BMI $25-29.9 \mathrm{~kg} / \mathrm{m}^{2}$ & BMI $21-22.9 \mathrm{~kg} / \mathrm{m}^{2}$ & RR $1.95(1.44,2.65)$ \\
\hline & HPFS & BMI $30-34.9 \mathrm{~kg} / \mathrm{m}^{2}$ & BMI $21-22.9 \mathrm{~kg} / \mathrm{m}^{2}$ & RR $2.33(1.62,3.36)$ \\
\hline & HPFS & BMI $\geq 35 \mathrm{~kg} / \mathrm{m}^{2}$ & BMI $21-22.9 \mathrm{~kg} / \mathrm{m}^{2}$ & RR $2.97(1.73,5.10)$ \\
\hline & ARIC (women) & BMI $30-34.9 \mathrm{~kg} / \mathrm{m}^{2}$ & $\mathrm{BMI}<25 \mathrm{~kg} / \mathrm{m}^{2}$ & RR $2.76(1.40,5.44)$ \\
\hline & ARIC (women) & BMI $\geq 35 \mathrm{~kg} / \mathrm{m}^{2}$ & BMI $<25 \mathrm{~kg} / \mathrm{m}^{2}$ & RR $3.90(1.95,7.82)$ \\
\hline & Framingham Heart (men) & BMI $25-29.9 \mathrm{~kg} / \mathrm{m}^{2}$ & BMI $<25 \mathrm{~kg} / \mathrm{m}^{2}$ & RR $1.76(1.22,2.54)$ \\
\hline & Framingham Heart (men) & BMI $\geq 30 \mathrm{~kg} / \mathrm{m}^{2}$ & $\mathrm{BMI}<25 \mathrm{~kg} / \mathrm{m}^{2}$ & RR $2.90(1.89,4.44)$ \\
\hline & Framingham Heart (women) & BMI $25-29.9 \mathrm{~kg} / \mathrm{m}^{2}$ & BMI $<25 \mathrm{~kg} / \mathrm{m}^{2}$ & RR $1.44(0.88,2.37)$ \\
\hline & Framingham Heart (women) & BMI $\geq 30 \mathrm{~kg} / \mathrm{m}^{2}$ & BMI $<25 \mathrm{~kg} / \mathrm{m}^{2}$ & RR $2.74(1.65,4.58)$ \\
\hline \multirow[t]{5}{*}{ Hypertension } & THIN & Hypertension & No hypertension & OR $1.18(1.13,1.23)$ \\
\hline & HPFS & Hypertension & No hypertension & RR $2.31(1.96,2.72)$ \\
\hline & ARIC & Hypertension & No hypertension & HR $2.00(1.52,2.61)$ \\
\hline & Framingham Heart (men) & Hypertension & No hypertension & RR $1.59(1.12,2.24)$ \\
\hline & Framingham Heart (women) & Hypertension & No hypertension & RR $1.82(1.06,3.14)$ \\
\hline \multirow[t]{4}{*}{ Diabetes mellitus } & THIN (men) & Diabetes mellitus & No diabetes mellitus & RR $0.59(0.55,0.64)$ \\
\hline & THIN (women) & Diabetes mellitus & No diabetes mellitus & RR $0.90(0.80,1.00)$ \\
\hline & THIN & Type I diabetes mellitus & No diabetes mellitus & RR $0.33(0.24,0.46)$ \\
\hline & THIN & Type II diabetes mellitus & No diabetes mellitus & RR $0.69(0.64,0.73)$ \\
\hline \multirow[t]{2}{*}{ Chronic renal failure } & THIN & Chronic renal failure & No chronic renal failure & OR $2.48(2.19,2.81)$ \\
\hline & HPFS & Chronic renal failure & No chronic renal failure & RR $3.61(1.60,8.14)$ \\
\hline
\end{tabular}

ARIC, Atherosclerosis Risk in Communities; HPFS, Health Professionals Follow-up Study; HR, hazards ratio; OR, odds ratio; RR, relative risk; THIN, The Health Improvement Network 